\title{
An Unusual Presentation of Brenner Tumor from Northern Pakistan
}

\author{
Paras Abbas $^{1 *}$, and Humera Mahmood ${ }^{2}$ and Mohammad Faheem ${ }^{3}$ \\ ${ }^{1}$ Post graduate trainee FCPS, Atomic Energy Cancer Hospital NORI Islamabad, Pakistan \\ ${ }^{2}$ Head Oncology Department, Atomic Energy Cancer Hospital NORI Islamabad, Pakistan \\ ${ }^{3}$ Chief Oncologist and Director, Atomic Energy Cancer Hospital NORI Islamabad, Pakistan
}

Submission: May 29, 2020; Published: June 11, 2020

*Corresponding author: Paras Abbas, Post graduate trainee FCPS, Atomic Energy Cancer Hospital NORI Islamabad, Pakistan

\begin{abstract}
Brenner tumors are rare surface epithelial stromal tumors that account for less than 1-2\% of ovarian malignancies. Brenner tumor can be benign, borderline, and malignant. Benign Brenner tumor is common as compared to malignant Brenner tumors. They tend to occur mostly in post-menopausal women. About $90 \%$ of Brenner tumors are unilateral. Here we present a 66-year-old female diagnosed with malignant Brenner tumor in one ovary and benign Brenner tumor in opposite ovary simultaneously.
\end{abstract}

Keywords: Brenner Tumor; Malignant Brenner tumor; Benign Brenner tumor

\section{Introduction}

Brenner tumors are divided into benign, which comprise of 95\% of Brenner tumors, borderline Brenner

(proliferative) and malignant Brenner tumors, which are extremely rare and comprise of less than 5\% [1] of Brenner tumours. Brenner tumors are usually asymptomatic unless the tumor size is very large, but it can cause abdominal distension [2] lower abdominal pain, post-menopausal bleeding and symptoms related to bladder (pressure effects).

\section{Case}

A 66-year-old post-menopausal woman presented in oncology department of AECH NORI, with the history of progressively increasing abdominal distension for about 6 months. It was not associated with pain or any other urinary or gynecological symptoms. Her ultrasound abdomen pelvis was done which showed no mass lesion and normal sized ovary on left side while there was a complex lesion measuring $138 \times 12.8 \times 8.2 \mathrm{~cm}$ in right adnexa. Right ovary was not separately visualized. Her CT scan showed a large well defined, soft tissue attenuation complex pelvis mass measuring $12.7 \times 10.7 \times 13.8 \mathrm{~cm}$ in midline slightly more towards right; the lesion had solid as well as cystic components with areas of calcification but no internal fat. No pelvic lymph node enlargement or fluid collection was seen. Patient underwent exploratory laparotomy. Total abdominal hysterectomy with bilateral salpingo-oophorectomy was done and peritoneal washings were taken On gross examination the left ovary was $3 \times 1.5 \times 1 \mathrm{~cm}$ and was attached to fallopian tube, cut surface of the ovary was unremarkable, while the specimen of right ovary comprised of a cyst attached to fallopian tube, the cyst was $14 \times 12$ $\mathrm{cm}$ and fallopian tube $10 \mathrm{x} 0.3 \mathrm{~cm}$ in size. It showed solid and cystic areas, it contained yellowish fluid and foci of necrosis were seen.

Histological examination of the right ovarian cyst revealed malignant Brenner tumor. It was composed of groups, sheets and papillary structures lined by rounded cells with central nuclei and eosinophilic cytoplasm. Areas of pleomorphism, spindling and mitosis were seen, nuclear grooving was identified. There was stromal invasion. Large areas of necrosis identified. No lymphovascular and perineural invasion was seen. Section of left ovary revealed foci of benign Brenner tumor; it was composed of solid and cystic nests of benign epithelial cells resembling transitional epithelium. The surrounding stroma was dense and fibroblastic. No malignant cells were seen. The malignant Brenner tumor was staged as T1cNoMo. Preoperatively her CA-125 was $54.16 \mathrm{U} / \mathrm{ml}$ and post operatively it dropped to $14.24 \mathrm{U} / \mathrm{ml}$ (Figures $1 \& 2)$.

\section{Discussion}

Brenner tumor arises from the surface epithelium of the ovary. Histologically it resembles transitional cell 


\section{Cancer Therapy \& Oncology International Journal}

carcinoma [3]. It can very rarely occur in vagina and testes. It usually occurs in post-menopausal females and mean age is 55 . Brenner tumor is a rare entity and due to rarity, its literature is not well established. Brenner tumor is usually unilateral but can occur bilaterally as malignant Brenner's. We report a case of bilateral Brenner tumor, right ovary malignant Brenner tumor and left benign Brenner tumor occurring simultaneously. Its symptoms are vague like any other ovarian malignancy; its usual presentation is abdominal distension or a mass in the lower abdomen. Our patient aged 66 years had abdominal distension and mass in her lower abdomen, and diagnosis was made after surgery. Mostly it is diagnosed incidentally and the cause of Brenner tumor is unknown. The main modality of treatment is surgical staging and the role of chemo radiation is not well established due to limited studies [4].

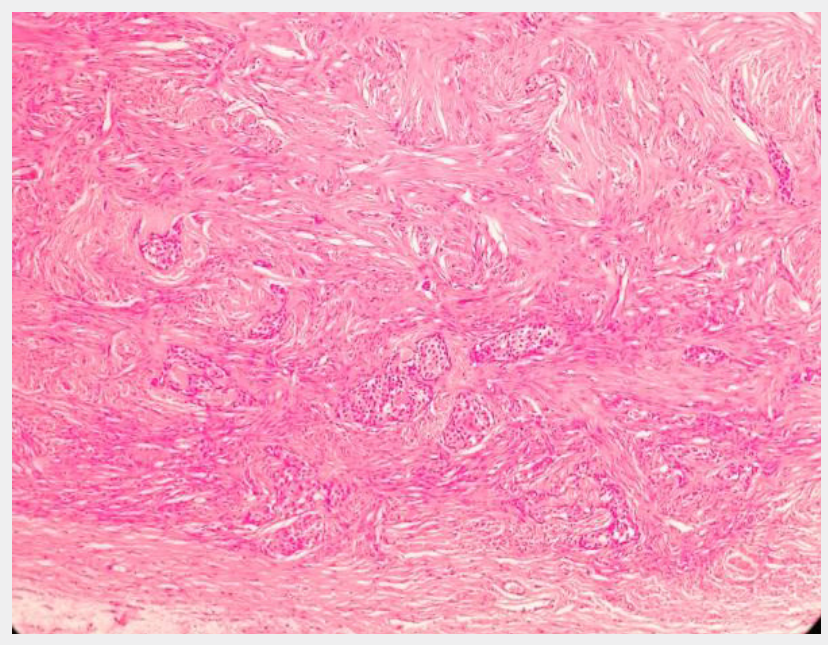

Figure 1: Benign Brenner tumor.



Figure 2: Malignant Brenner tumor.

There is no specific reliable tumor marker for Brenner's but CA-125 is reported to be raised in $30-70 \%$ of malignant Brenner tumor [4,5]. CA 125 is not a reliable marker but in our patient, it markedly dropped after surgery. IHC is usually done for the confirmation of Brenner's but in our case the diagnosis was clear on morphology. Prognosis is generally considered good and surgery is the main modality of treatment [5]. There is no single competent chemotherapy regimen established but platinumbased agents [6] and paclitaxel post-operatively has demonstrated survival benefits in small retrospective studies [6]. Our patient has also been planned for platinum-based adjuvant chemotherapy.

\section{Conclusion}

While reporting radiology and histopathology more varieties of epithelial ovarian tumors should also kept in mind so as not to miss the diagnosis and provide optimal treatment to the patient involving multidisciplinary team. 


\section{Cancer Therapy \& Oncology International Journal}

\section{Conflict of Interest}

The authors declare that there is no conflict of interest regarding the publication of this article.

\section{Funding}

The work received no specific grant from any funding agency in public, commercial and non-profit sectors.

\section{Patient Consent}

Written informed consent was taken from patient.

\section{References}

1. IARC Press; Lyon: 2003 In: World Health Organization Classification of Tumours. Pathology and Genetics of Tumors of the breast and Female Genital Organs; pp. 113-145

2. Gezginç K, Karatayli R, Yazici F, Acar A, Celik C, et al. (2012) Malignant
Brenner tumor of the ovary: analysis of 13 cases. Int J Clin Oncol 17(4): 324-329.

3. Ali R, Seidman J, Luk M, Kalloger S, Gilks C (2012) Transitional cell carcinoma of the ovary is related to high-grade serous carcinoma and is distinct from malignant Brenner tumor. Int J Gynecol Pathol 31: 499.

4. Ji-Hyun Han, Dae-Yeon Kim, Shin-Wha Lee, Jeong-Yeol Park, JongHyeok Kim, et al. (2015) Intensive systemic chemotherapy is effective against recurrent malignant Brenner tumor of the ovary: an analysis of 10 cases within a single center. Taiwan J Obstet Gynecol 54(2): 178182.

5. Nasioudis D, Sisti G, Holcomb K, Kanninen T, Witkin SS (2016) Malignant Brenner tumors of the ovary; a population-based analysis. Gynecol Oncol 142: 44-49.

6. Ozols RF, Bundy BN, Greer BE, Fowler JM, Clarke-Pearson D, et al (2003) Phase III trial of carboplatin and paclitaxel compared with cisplatin and paclitaxel in patients with optimally resected stage III ovarian cancer: a Gynecologic Oncology Group study. J Clin Oncol 21(17): 3194-3200.
This work is licensed under Creative Commons Attribution 4.0 License DOI:10.19080/CTOIJ.2020.16.555938
Your next submission with Juniper Publishers will reach you the below assets

- Quality Editorial service

- Swift Peer Review

- Reprints availability

- E-prints Service

- Manuscript Podcast for convenient understanding

- Global attainment for your research

- Manuscript accessibility in different formats

( Pdf, E-pub, Full Text, Audio)

- Unceasing customer service

Track the below URL for one-step submission https://juniperpublishers.com/online-submission.php 